\title{
ASSESSMENT OF ACTUAL POWER AND ELECTRIC POWER AT CONSTRUCTION SITES
}

\author{
Viktor Reznichenko', Valentin Demidov², Georgii Demidov³ \\ 1,2 Saint Petersburg State University of Architecture and Civil Engineering \\ Vtoraja Krasnoarmejskja ul. 4, St. Petersburg, 190005, Russia \\ ${ }^{3}$ NPK "Pelengator" \\ Ivana Chernykh ul. 31-33, lit. V, St. Petersburg,198095, Russia \\ 112356788@mail.ru, ${ }^{2}$ dvp52@mail.ru, ${ }^{3}$ kimuriell@gmail.com
}

\begin{abstract}
The article deals with issues connected with power supply of buildings and structures under construction. Due to nonlinear nature of electric power consumption at building industry enterprises, current and feeding voltage are distorted. This causes additional losses of actual power and energy, as well as inaccuracy and ambiguity in readings of power control devices and electric power metering. The article generalizes results of research on harmonic composition of electric power parameters of static converters and states recommendations on improvement of assessment and accounting of actual power and electric energy in electrical networks of building organizations.
\end{abstract}

Keywords: actual power, electric power, unsinusoidality, higher-order harmonic, idle-current wattmeter, electric power meter.

\section{Introduction}

Due to continuous increase in the number of electric equipment for construction industry which can be applied for non-linear loads, the problem of studying effects of such loads on losses of power and energy in electric power networks, as well as on accuracy and unambiguity of control and accounting of actual power and energy, increases constantly. Therefore, the problem of investigating the influence of non-linear loads on electric power networks, as well as development of methods and tools for assessment of power and energy, is becoming increasingly important.

\section{Methods of study}

Studying of scientific books, idealization, analysis, formal characterization, research and generalization of experience, forecasting.

\section{Results of studies}

Proper and timely solving of issues of construction power supply, i.e. supply of enough high quality electric power within the given timeframes, influences the terms of construction and installation works, effective operation of construction machines and mechanisms, and, finally, successful fulfillment of the development schedule to a large extent (Kononenko, 2008). The main objectives of electric power supply of construction can be expressed as follows:

- reduction of all types of power losses in electric power supply and at electric facilities of construction sites;

- implementation of energy-efficient construction technologies and introduction of combined electrical engineering processes;

- improvement of existing electric power facilities, engineering and implementation of new, more energy efficient electric power equipment, construction machinery and electric drive mechanisms;

- increasing organizational level of construction; establishing strict monitoring and accounting of power consumption at construction sites, including application of computer technologies; developing and improving science-based activities on metering of electricity consumption during construction and installation works; 
- introducing automated and automatic control of processes, building machines and mechanisms, and common use of microprocessor engineering.

Solving the majority of these tasks of quality electrical power supply to construction sites is closely connected with the need of reliable estimation of actual power and energy.

The peculiarity of electric power supply of construction sites is as follows (Kononenko, 2014; Chukayev, 1981):

1. A significant part of electric power networks (overhead and cable) is temporary and is designed, as a rule, without careful calculations. Partly for that reason, the quality of electricity on construction sites is often unsatisfactory. 2. Capacity of supply mains is often relatively small (medium-sized construction site requires 700-1500 kW/A electrical power).

3. The main electricity consuming units at construction sites are engines (asynchronous mainly); their capacity often equals the power of supply transformers.

4. A significant number of other power consumers at construction sites can be referred to power distorting units. These are personal computers, arc and resistance welding devices, gas-discharge lamps, etc.

Powerful static frequency converters are widely used for power supply of engines. The basis of the main circuits of static frequency converters is semiconductor devices, which are nonlinear elements. The work of static converters is based on wiring of groups of semiconductor rectifiers (diodes, silicon controlled rectifiers, transistors, IGBT modules). All wiring circuits of static frequency converters generate consumption of unsinusoidal current from power networks causing distortion of sine waves of electric line voltage (Vershinin, 2000). In general, the curves of current and voltage in electrical networks can be regarded as amplitude-modulated oscillations governed with a random law of changes in amplitude and the initial phase; the voltage can be expressed as follows

$$
u(t)=U_{m}(t) \sin (\omega t+\psi(t)),
$$

where $u(t)$ and $U_{m}(t)$ are instantaneous and amplitude values of voltage for a given time moment $\mathrm{t} ; \psi(t)$ is the initial phase.

The general equation for current $i(t)$ is similar by the structure. If nonlinear loads operate in steady state, then the equation for the current $i(t)$, supplied from the mains by the converter, is expressed with the Fourier series (Zhezhelenko, 2000):

$$
i(t)=\sum_{v=1}^{n} I_{v m} \sin \left(v \omega t+\psi_{v}\right)
$$

where $I_{v m} \sin \left(v \omega t+\psi_{v}\right)$ are harmonics or harmonic compounds of the order $v$ with the amplitude $I_{v m}$ and the initial phase $\psi v ; n$ is the order (number) of the last accounted higher harmonic.

The output current of the inverter (2) may consist of different types of harmonics, so it should be presented as follows (Zhezhelenko, 2000; Arrillaga, Bradley and Bodger, 1985; Mayevsky, 1965; Khanzelka and Bien, 2005):
$i(t)=I_{0}+I_{1 m} \sin \left(\omega t+\psi_{1}\right)+\sum I_{S H}+\sum I_{C H}+\sum I_{N H}+\sum I_{I H}$

where $I_{0}$ is a DC component; $I_{1 m} \sin \left(\omega t+\psi_{1}\right)$ is the current of the main component; $\sum^{1 m} I_{S H}$ is the total of subharmonic frequencies; $\sum I_{C H}$ is the total of higher characteristic harmonics; $\sum I_{N H}$ is the total of higher

non-characteristic harmonics; $\sum I_{I H}$ is the total current of interharmonics.

In general, the major possible components of the output current of the frequency converter can be represented in a tabular form (see Table 1):

Table 1. Components of the output current of the frequency converter

\begin{tabular}{|c|c|}
\hline $\begin{array}{c}\text { Components of output current of } \\
\text { the converter }\end{array}$ & Frequency, $1 / \mathrm{s}$ \\
\hline Steady component & $\omega=0$ \\
\hline Main component & $\begin{array}{c}\omega=\omega n=2 \pi f n, \text { where } \mathrm{fn}=50 \mathrm{~Hz}- \\
\text { network frequency }\end{array}$ \\
\hline $\begin{array}{c}\text { Higher characteristic harmonics } \\
\text { Higher non-characteristic har- } \\
\text { monics (abnormal) }\end{array}$ & $\begin{array}{c}\omega=(2 \mathrm{p}+3) \mathrm{fn} \text {, where } \mathrm{p}=0,1,2, \ldots ; \\
\mathrm{n}=1,2,3, \ldots ; \mathrm{f}>\mathrm{fn}\end{array}$ \\
\hline Subharmonics & $\omega=\omega \mathrm{n} / \mathrm{k}$, where $\mathrm{k}=2,3,4, \ldots ; \mathrm{f}<\mathrm{fn}$ \\
\hline $\begin{array}{c}\text { Abnormal (non-characteristic) } \\
\text { harmonics (interharmonics) }\end{array}$ & $\omega \neq \mathrm{h} \omega \mathrm{n}$, where $\mathrm{h} \neq 2,3,4, \ldots ; \mathrm{f}>\mathrm{fn}$ \\
\hline
\end{tabular}

Depending on the type of converter, the output current is different, which means that the expression (3) may or may not include certain components.

For example, harmonic frequencies are not generated under continuous cyclic control based on half cycles of alternating current, though interharmonics and subharmonics appear (Arrillaga, Bradley and Bodger, 1985).

It should be noted that the present classification of output current of the static frequency converter is conventional. Impulsive and fluctuating distortions appear under non-linear loads. They generate components of continuous spectrum, its energy regarded insignificant for power supply issues in comparison with the power of harmonic components (Zhezhelenko, 2000). However, it is believed that this issue is not yet sufficiently investigated.

Unsinusoidality and unbalance of voltage and current influence losses of power and energy in electrical networks.

Additional technical losses in the electric network are inconsistent if voltage unsinusoidality is less than $5 \%$; total power losses increase significantly if unsinusoidality coefficient KU increases up to $10-15 \%$. The greatest losses of higher harmonics in elements of the electric power system occur under resonant modes (Sharov, 2006).

Methods for calculating losses in electric equipment developed by various authors are approximate due to various reasons. Thus, frequency characteristics of actual and reactive electric resistance are average, specific to the type of equipment (motors, transformers, capacitors, etc.). Nonlinearities of these characteristics are deter- 
mined with coefficients which are usually different for various frequencies. Impact of skin effect and proximity effect is described with the coefficient that depends on the number of harmonics. Impact of conductor resistance temperature is not considered. Attempts to evaluate the default level of estimation of additional losses were made. To this end, they performed calculations according to well-known methods for specific cases. It was found that calculation errors are positive for higher harmonic frequencies up to 13th harmonic order inclusive, not exceeding $7 \%$ and totaling up to $5 \%$ for $95 \%$ of cases (Shidlovsky, 1985). This applies to calculations of frequencies of characteristic harmonics. Errors of calculation of losses in frequencies of interharmonics have not been sufficiently studied, as "standardization in the field of interharmonics is in the process of accumulation of knowledge" (Zhezhelenko, 2012). According to recommendations of the International Electrotechnical Commission (IEC), voltage interharmonics are limited to $0.2 \%$ in the frequency range up to $2 \mathrm{kHz}$.

Additional harmonics also cause additional inaccuracies in power accounting.

All existing electric power metering devices can be roughly classified in accordance with the base of elements they are made of and measurement principles allowing recording and can be inductive, electronic and microprocessor devices (Sharov, 2006). The quality of electric power affects the work of metering devices in different ways.

Two electrical counterstreams circulate during measurement of actual power of nonlinear loads $P_{\mathrm{NL}}$ power supplied from the network $\mathrm{P}_{1}$ (power of the main component) and power of additionally generated harmonics of different frequencies (depending on the type of static frequency converter) $\sum_{2}^{n} \mathrm{P}_{n}$

Nonlinear loads PNL are a source of additional harmonics, that is why:

$$
P_{N L}=\mathrm{P}_{1}-\sum{ }_{2}^{n} \mathrm{P}_{n}
$$

Linear loads under unsinusoidality voltage can be determined as follows:

$$
P_{L}=\mathrm{P}_{1}+\sum{ }_{2}^{n} \mathrm{P}_{n}
$$

The frequency response of the accuracy of an induction watthourmeter at the frequency of the harmonic $n$ is approximated by the following equation (Ponomarenko, 2003):

$$
\gamma=\alpha(\exp (-\beta \cdot n)-1), \text { where } \alpha=1.28 \text { and } \beta=1.19 \text {. }
$$

In accordance with this feature and the equation (4), overestimation of electricity is registered during calculation of electric power consumed by non-linear loads, and underestimation is identified for linear loads (5) under unsinusoidality voltage. Thus, the consumer pays for deterioration of the electric power quality due to distorting loads in the electric network, if an induction watthourmeter is installed at a fiscal metering point. However, total balanc- es of overestimation (underestimation) are not registered for the power supply system (Zhelezko, 2009; Shildovsky, 1985; Zhezhelenko, 2012).

Electronic and microprocessor metering devices may identify direction of voltage of higher harmonics at the point of registration, in contrast to induction watthourmeters. As a result, the consumer pays less for the electricity with the source of distortion, while the consumer receiving electricity of higher harmonics pays more than if it receives electric power with sinusoidal voltage.

Based on the aforesaid, it is evidently impossible to produce sufficiently accurate calculation of actual power and energy losses that are present in electric networks. It is also impossible to assess actual power consumption. The possible way out is measurement of actual power and the power consumed from the mains. Comparison of the actual power and energy with designed values can help to determine "standard" losses of power and energy.

Measurement of electric power wattage is one of the main types of measurements in many fields of human activities, and in the power sector in particular. Accuracy of wattage measurement means (WMM) determine the accuracy of measurement and metering of electric power, wattage coefficient, performance of machines and devices. Improving of WMM accuracy can create significant economic benefits. Until recently, the electricity needs were mostly satisfied with industrial frequency WMM with the basic error of less than $0.5 \%$, while high-end devices were used as calibration devices (Bezikovich, 1980).

A few works on power measurement issues, published at the beginning of the second half of the 20th century, were devoted to such WMM. Development of modern automated systems of metering and distribution of electricity taking into account current features of electricity consumers demanded designing of working WMM with the basic error of less than $0.1 \%$ on the industrial rate, significant improvement of accuracy of broadpassband and low power-factor WMM, as well as development of high-speed digital WMM. Solving of these issues is associated with development of new methods and means of metrological support.

Development of digital wattmeters is aimed at solving two problems, as a rule: engineering of high-speed high-precision broadpassband instruments (class of 0.01-0.05) for research and metrological works, and designing of general precision instruments (class of 0.1-0.5) with a narrow frequency range of $50-1000 \mathrm{~Hz}$, characterized with high reliability, adaptability, small size and cost for mass use in power systems and electronic power meters (Bezikovich, 1980). However, such devices do not cover the entire frequency range, as the measured signal may contain sub-harmonics (oscillations with the frequency less than $50 \mathrm{~Hz}$ ) and harmonics with the frequency above $1000 \mathrm{~Hz}$ (Schneider Electric specialists believe that the harmonics of up to 13th order should be corrected obligatory, meanwhile effective correction is possible under consideration of harmonics up to the 25th order $(1250 \mathrm{~Hz})$. It can be assumed that it would be necessary to account higher harmonics in the future, since the same special- 
ists of Schneider Electric believe that harmonic currents above the 50th order are insignificant and can be neglected; that means that lower order harmonics should still be taken into account (Sazhenkov, 2009).

Specific features of AC power metering are that WMM is affected with three physical quantities (traditional approach): voltage, current and wattage factor. In this case, the very measured value, the wattage, does not affect directly the measuring transmitter. Accuracy of wattage measurement in this case is determined with the accuracy of three measurement errors of these quantities, which are characterized by different factors, including the properties of the load.

Measurement of feed-through power is usually performed by determining on-load voltage and current feeding through. In accordance with the accepted terminology (GOST 16263-70), measurements of wattage can be attributed to direct measurements, when the result of conversion is proportional to the product of initial values, none of which is defined at any conversion stages (wattmeter method), or to indirect measurements, when original values are defined and their product is calculated (method of ammeter and voltmeter). In this sense, conventional electricity meters and wattmeters are devices with direct measurement of power and energy. Currently there are metering devices, which comply with today's requirements for such devices. Most CIS manufacturers use an element base and technologies of the leading companies in the world. Thus, the EPQS device metering actual, reactive and full energy is a multifunctional measuring instrument complying with the requirements of the international standard IEC 60687 (Zhezhelenko 2012). The considered EPQS measuring device is similar to SL7000 Smart applying the principle of conversion of measured values and having the same characteristics, but the former is available in the CIS. The high engineering level of Western European metering devices is based on unique technologies. Thus, the company Siemens Metering Ltd (Switzerland) produces electricity meters based on such measuring elements, as Hall transducers. Hall transducers make direct measurements of actual power of individual phases (in the above stated sense) and generate pulses pro rata the power with high precision (Zhezhelenko, 2012). It should be taken into account that these new transducers of metering devices are still affected not by power itself, but its components. Considering specific models of metering devices, it can be stated, that measuring accuracy increase significantly when changing measurements from DC current into AC current.

An alternative to traditional methods of low-frequency power measurement is thermal methods, implying conversion of the measured power (energy) directly into an output signal or comparison of the measured power with a stated DC wattage. The calorimetric method is widely used to measure high frequency and ultra-high frequency power (Spektor, 1987; Remez, 1956).

In principle, the colorimetric method can be applied for power metering of the whole spectrum of frequencies of electromagnetic oscillations (Bilko, 1976).

At present, deviations of the curve of the measured voltage or current from an ideal sine wave lead to incorrect re- sults of current metering in modern power networks by voltage or current meters with average readings. In this regard, they developed instruments that measure the so-called actual rms values of $A C$ voltage and current of any form, which are determined with heating of an ohmic resistor fed from the measuring voltage (Dyakonov, 2011). Modern multimeters which measure true RMS of AC voltage and current (not necessarily sinusoidal) are marked as True RMS, as a rule. In fact, these devices involve thermal methods.

Therefore, power measurement of unsinusoidality processes with a wide harmonic composition requires the use of thermal methods.

Thermal power measurement methods are suitable for all frequencies, but actually applied only for very high frequencies.

Besides thermal methods, there are other methods that have not been traditionally used for engineering of commercial power (energy) measurement devices, described in detail in the scientific literature (Bezikovich, 1980). There were unique measuring devices even in the Soviet Union; their characteristics are not inferior, and sometimes even superior to that of modern instruments developed abroad (Dyakonov, 2011). Such experience of engineering these devices could be used to develop instruments of power control and energy measurement, which would comply with modern requirements. It is required to design such devices, that would allow reliable monitoring and metering of power and energy, as well as to develop calibration devices of high accuracy.

Although modern measuring devices present at the Russian market are called electronic, microprocessor and intelligent, they are not intended for reliable control and metering (according to the information available, mainly advertising), but are aimed at meeting increasing requirements of power supply companies. The following characteristics of "smart" metering devices are focused in the available works (Osika, 2011):

- protection against unauthorized actions;

- automatic readings;

- imposition of penalties on defaulters;

- secure data storage, etc.

\section{Results of study}

- Results of harmonic analysis of static frequency converters of various types are summarized.

- Recommendations on improvement of power and energy estimation at construction sites are given.

\section{Conclusions}

1. Currently available devices for control and metering of actual power and electricity do not provide reliable information on quantitative values of these parameters due to characteristics of modern electric power consumers.

2. It is necessary to use power and energy metering devices with reliable readings in order to assess accuracy of power and energy values. The most appropriate devices for measuring are those ones applying thermal methods. 
3. Since there are no calorimetric instruments for metering power and energy in electricity networks at present time, it is necessary to develop and introduce such devices.

4. At present day, existing devices can measure actual power and energy allowing for harmonic voltage or spectral analysis in the electric network and the load current.

5. Sensitive measuring instruments designed for measuring audio-frequency range can be used as a reference for calibration of existing power control and metering devices.

\section{References}

Arrillaga, J., Bradley, D. and Bodger, P. (1985). Power System Harmonics. Chichester: John Wiley \& Sons.

Bezikovich, A. (1980). Measurement of electric power in the audio frequency range [lzmerenie jelektricheskoj moshhnosti $v$ zvukovom diapazone chastot]. Leningrad: Energia, Leningrad department (in Russian).

Bilko, M. (1976). Measurement of power of super-high frequencies [Izmerenie moshhnosti na SVCh]. Moscow: Sovetskoe radio (in Russian).

Chukayev, D. (1981). Textbook for technical schools on electrical systems of machines and power supply of construction sites [Jelektrooborudovanie stroitel'nyh mashin i jenergosnabzhenie stroitel'nyh ploshhadok: Uchebnik dlja tehnikumov]. 2nd edition, revised and enlarged. Moscow: Stroyizdat, (in Russian).

Dyakonov, V. (2011) Digital measurements in nanotechnologies and microelectronics [Jelektronnye izmerenija $v$ nanotehnologijah i mikrojelektronike]. Moscow: DMK Press (in Russian).

Khanzelka Z., Bien A. (2005). Interharmonics [Intergarmoniki]. Energosnabzhenie, No. 7/2005, pp. 80-84.

Kononenko, V. (2008) Textbook for higher schools: electrical engineering and electronics [Jelektrotehnika i jelektronika: uchebnoe posobie dlja vuzov]. 4th edition. Rostov-on-Don: Feniks (in Russian).

Kononenko, Ye. (2014). Features of power enterprises of the construction industry and construction sites. Actual energy problems [Osobennosti jelektrosnabzhenija predprijatij stroitel'noj industrii i strojashhihsja objektov. Aktual'nye problemy jenergetiki]. SNTK 69, Repository of the Belorussian National Technical University (in Russian).

Mayevsky, O. (1965). Determination of power relations and components of gross output of valve converter installations [Opredelenie jenergeticheskih sootnoshenij i sostavljajushhih polnoj moshhnosti v ventil'nyh preobrazovatel'nyh ustanovkah]. Electricity, 3, pp. 7-14 (in Russian).

Osika, L. (2011). Smart metering - intelligent metering of electrical power [Smart metering — «intellektual'nyj uchet» jelektrojenergii]. The News of Electrical Engineering, 5(71). Available at: http://www.news.elteh.ru/arh/2011/71/14.php accessed on 20 July 2016 (in Russian).

Ponomarenko I. (2003) Effects of unsinusoidal voltage on performance of electronic electricity meters [Vlijanie nesinusoidal'nosti naprjazhenija na rabotu jelektronnyh schetchikov jelektrojenergii]. Materials of scientific and research conference. Moscow: NTs ENAS (in Russian).

Remez G. (1956). Course of main radio measurements [Kurs osnovnyh radiotehnicheskih izmerenij]. 2nd edition. Moscow: State publishing house for communications and radio literature (in Russian).

Sazhenkov V. (2009). Measurement and correction of harmonics [lzmerenie i ustranenie garmonik]. Technical literature of Schneider Electric, Issue 30 (in Russian).

Sharov Yu. (2006). Electrical power quality control [Upravlenie kachestvom jelektrojenergii]. Moscow: Izdatelsky dom MEI (in Russian).

Shidlovsky A. (1985). Improving power quality in electrical networks [Povyshenie kachestva jenergii v jelektricheskih setjah]. Kiev: Naukova Dumka (in Russian).

Spektor S. (1987). Textbook for higher schools on electrical measurements of physical quantities. Measurement Methods [Jelektricheskie izmerenija fizicheskih velichin: Metody izmerenij: Uchebnoe posobie dlja vuzov]. Leningrad: Leningrad Department of Energoatomizdat (in Russian).

Vershinin, V. (2000). Lecture notes on electromagnetic and electromechanical compatibility in electrical systems with semiconductor converters [Jelektromagnitnaja i jelektromehanicheskaja sovmestimost' $v$ jelektrotehnicheskih sistemah s poluprovodnikovymi preobrazovateljami: Konspekt lekcij]. Saint Petersburg: Saint Petersburg Mining Institute (in Russian).

Zhelezko, Yu. (2009). Guidelines for practical calculations of electricity losses, reactive power and power quality [Poteri jelektrojenergii. Reaktivnaja moshhnost'. Kachestvo jelektrojenergii: Rukovodstvo dlja prakticheskih raschetov]. Moscow: ENAS (in Russian).

Zhezhelenko, I. (2000). Higher harmonics in power supply systems of industrial enterprises [Vysshie garmoniki v sistemah jelektrosnabzhenija prompredprijatij]. 4th edition, revised and enlarged. Moscow: Energoatomizdat (in Russian).

Zhezhelenko, I. (2012). Electromagnetic compatibility of consumers [Jelektromagnitnaja sovmestimost' potrebitelej]. Moscow: Mashinostroenie (in Russian). 